\title{
Artefakt kulturowy w humanistyce
}

\begin{abstract}
Grodecka Aneta, Artefakt kulturowy w humanistyce [A cultural artifact in the humanities]. „Przestrzenie Teorii” 23. Poznań 2015, Adam Mickiewicz University Press, pp. 53-69. ISBN 978-83-232-2920-9. ISSN 1644-6763. DOI 10.14746/pt.2015.23.4.
\end{abstract}

This article is devoted to the concept of an artifact, as derived from older methodological knowledge (J. Białostocki and E. Panofsky), which has been broadened to include new indicators, such as changes of the virtual era as well as the categories of experience and reflections on narration. By reconstructing the phenomenon of artifacts, the author refers to the category of 'reality' according to Heidegger and W. Toporow as well as the ideas of a 'sign' and 'theme', and Polish artistic practice (T. Kantor and Z. Herbert). The concept is situated within the arts as well as within a contextualized area of the social sciences (an actant) and aims to offer new perspectives on the study of culture.

\author{
...nieożywiony materiat rzeczy \\ może służyć za lustro ruchliwego ludzkiego ducha...
}

Władimir N. Toporow, Przestrzeń i rzecz

„Artefakt” stał się współcześnie bohaterem tendencji kulturowej, którą określa się jako „zwrot ku rzeczom”, kojarzonej z hasłami „humanistyki nie-antropocentrycznej” lub „humanistyki ekologicznej” (zaproponowanymi przez Ewę Domańską1). W naukach społecznych uruchamia siatkę synonimów, takich: jak aktant, narzędzie, eksponat, fetysz, towar, śmieć, semiofor ${ }^{2}$, w nauce o sztuce i literaturze zaczyna funkcjonować w grupie pokrewnych terminów, jak „motyw”, „topos”, „tekst kultury”. W czasie badań dotyczących operacji wykonywanych na obrazach przechowywanych $\mathrm{w}$ pamięci ${ }^{3}$ wykryto, że przebiegają one w sposób analogiczny do działań na rzeczywistych przedmiotach, że można nimi manipulować jak przedmiotami fizycznymi: dzielić je, przesuwać, obracać. Zakres myślenia o dziełach sztuki poszerzają również współczesne koncepcje dotyczące „figur myśli”", związane z neurologicznymi uwarunkowaniami procesów twórczych. Odkrycie powyższych mechanizmów przeczy wielowiekowej tradycji myślenia o artefaktach, sprawia, że możemy mówić współcześnie

1 Zob. E. Domańska, Humanistyka nieantropocentryczna a studia nad rzeczami, „Kultura Współczesna” 2008, nr 3; taż, Humanistyka ekologiczna, „Teksty Drugie” 2013, nr 1/2.

2 K. Pomian, Historia. Nauka wobec pamięci, Lublin 2006, s. 100-101.

${ }^{3}$ M. Jagodzińska, Psychologia pamięci. Badania. Teorie. Zastosowania, Gliwice 2008.

${ }^{4}$ R. Schrott, A. Jacobs, Gehirn und Gedicht. Wie wir unsere Wirklichkeiten konstruieren, München 2011. 
o nowym stosunku do „rzeczowości” i „zjawiskowości”. Sądzę, że zwrócenie uwagi na przedmiot $\mathrm{w}$ procesach interpretacji może odsłonić nieznane wcześniej aspekty naszej tożsamości, co skłania mnie do stworzenia koncepcji badawczej, którą $\mathrm{w}$ formie szkicowej przedstawię w niniejszym artykule ${ }^{5}$.

\section{Przedmioty na pograniczu social i arts}

Otaczanie się przedmiotami to cecha fundamentalnie ludzka, która odróżnia nas od zwierząt. Zwykle o wartości człowieka zaświadczał stopień oddalenia od świata rzeczy lub przynajmniej jego gotowość do porzucenia sfery materialnej. To przedmioty ${ }^{6}$ wyznaczały kierunek rozwiązań technologicznych, te ważne, jak np. igła, pieniądz, koło, wiatrak, okulary, fotografia, telefon komórkowy, decydowały o kierunku rozwoju naszej cywilizacji. Sposób, w jaki traktowaliśmy przedmiot, zawsze zależał od obowiązującego $\mathrm{w}$ danej chwili stopnia natężenia antropocentryzmu i w pewien sposób od warunków zewnętrznych. Dwie wojny światowe wprowadziły spory dysonans w dziedzinie kolekcjonowania pięknych przedmiotów, a pomysły związane ze sztuką konceptualną w XX wieku podważyły status przedmiotu w praktyce artystycznej. Duże znaczenie odegrała również ideologia Marksa, niechętnego, by sferę kultury materialnej zanieczyszczać refleksją antropologiczną, co przekładało się na sposób badania tejże kultury w Polsce w latach pięćdziesiątych, gdy dominowała etnograficzna rejestracja zabytków kultury ludowej, a obowiązywały typowe dla nauk przyrodniczych metody dochodzenia do wiedzy: systematyka, typologie, szczegółowe opisy. Przedmiot - jako wytwór ludzki - bywa często nazywany „artefaktem”, a to pojęcie, zgodnie z wykładnią Mieke Bal, można uznać za typowe „pojęcie wędrujące”, płynne w swoich

5 Artykuł jest rozszerzoną wersją referatu Artefakty kulturowe jako ptaszczyzna dialogu między literatura a sztukami plastycznymi wygłoszonego na sesji Literatura $w$ obszarach innych sztuk. Problemy metodologiczne, zorganizowanej przez Zakład Badań Kulturowych Instytutu Filologii Polskiej Uniwersytetu Jana Kochanowskiego w Kielcach w 2013 roku.

${ }^{6} \mathrm{O}$ roli przedmiotów w kulturze pisali m.in. O. Kwiatkowska, A. Kola, O przywróceniu zachwianej równowagi antropologicznej. Głos podwójny w kwestii przedmiotów, [w:] Kultura profesjonalna etnologów w Polsce, red. M. Brocki, K. Górny, W. Kuligowski, Wrocław 2006; M. Krajewski, Sa $w$ życiu rzeczy... Szkice z socjologii przedmiotów, Warszawa 2013; E. Bińczyk, „Zwrot ku rzeczom” we wspótczesnej humanistyce, [w:] Technonauka $w$ społeczeństwie ryzyka. Filozofia wobec niepożądanych następstw praktycznego sukcesu nauki, Toruń 2012.

7 Zob. M. Bal, Wędrujące pojęcia $w$ naukach humanistycznych: krótki przewodnik, przeł. M. Bucholc, Warszawa 2012. 
znaczeniach. Jego definicja zanotowana przez Władysława Kopalińskiego ulega współcześnie przeformułowaniu ${ }^{8}$, a zakres posługiwania się terminem znaczącemu, interdyscyplinarnemu poszerzeniu.

Charakterystyka przedmiotów to domena m.in. archeologii, socjologii, kulturoznawstwa, antropologii, a ostatnio również „technonauki”. Archeolodzy definiują artefakty jako obiekty przenośne, zaliczając do tej grupy m.in. narzędzia kamienne, ceramikę, broń wykonaną z metalu; niektórzy obejmują tą nazwą także elementy krajobrazu przekształcone ręką ludzką, takie jak: paleniska, jamy, rowy, spichlerze, domy mieszkalne i świątynie; umieszczając poza kategorią artefakty naturalne ekofakty, czyli kości zwierzęce, pozostałości roślinne, a także gleby i warstwy osadowe. W ujęciach badaczy przeszłości każde śmietnisko staje się archiwum ludzkich zachowań i wartości, rzadko jednak takie badania zyskują wymiar uniwersalny, rzadko historia przedmiotu przekracza granice pomiędzy epokami lub kulturami. W sposób szeroki traktuje pojęcie socjologia; w ramach jej terminologii artefakty to wszelkie przedmioty, zjawiska i procesy niebędące wytworem przyrody, a zainicjowane przez człowieka, czyli np. logo firmy, obowiązujący w niej wzór zachowań (rytuały, obrzędy), ale i język (anegdota, dowcip, opowieść, mit, metafora, żargon). Szczególny status zyskują przedmioty w ramach antropologii, gdzie traktuje się je jako czynniki pozaludzkie, najczęściej wytwory technologii tworzące sieć powiązań w wyjątkowej, niespotykanej wcześniej, skali. Nośna okazała się metafora Brunona Latoura, który w latach siedemdziesiątych XX wieku ujął artefakt w sposób kompleksowy, uznając go za „aktora sieci” (ANT, „Actor-Network Theory”), obiekt, będący wynikiem sieci procesów, który stanowi rezultat zamknięcia „czarnej skrzynki”, kres konkretyzacji idei ${ }^{9}$ „AActant” (aktant) współtworzy sieć mechanizmów translacji, analogicznie jak aktywne semantycznie podstawowe schematy narracyjne ${ }^{10}$ lub $\mathrm{w}$ dramaturgii wszelkie elementy ożywione lub nieożywione mogące wpłynąć na przebieg zdarzenia ${ }^{11}$. Zgodnie z zało-

8 W Wielkiej encyklopedii (red. J. Wojnowski, Warszawa 2002) autorzy hasła wyróżniają artefakt $\mathrm{w}$ ramach archeologii, nauk biologicznych oraz wyodrębniają i definiują grupę artefaktów kulturowych.

9 Opis idei w: K. Abriszewski, Poznanie, zbiorowość, polityka. Analiza teorii aktora-sieci Bruno Latoura, Kraków 2012.

10 Aktant odgrywa rolę analogiczną do ról narracyjnych, takich jak: „acteur”: ten, kto działa, „agent”: ten, przez kogo dokonuje się działanie, „objet patient”: to, co podlega działaniu, „bénéficiaire”: ten, kto zbiera rezultaty działania, „instrument”: to, co pozwala na działanie. Dopowiedzenie dotyczące roli aktantu w kulturze francuskiej zawdzięczam dr. Tomaszowi Chomiszczakowi.

11 Klasyfikacje postaci teatralnych ze względu na ich możliwe relacje w studium E. Souriau Les 200000 situations dramatiques, Paryż 1950; ten temat (aktanty, modele 
żeniami teorii Latoura, człowiek i czynniki pozaludzkie automatycznie wchodzą ze sobą w rozmaite relacje, a to przeczy założeniom tradycyjnej humanistyki, gdzie podmiot oznaczał zwykle rodzaj energetycznego centrum. Podobnie jak socjolog francuski artefakt analizowali m.in.: Thomas Hylland Eriksen, który rozważając rolę zegarka, pieniędzy, książki $\mathrm{w}$ historii ludzkości, wyraził przekonanie, że przedmioty zaczynają nas prześcigać; Igor Kopytoff, który odtwarzał życiorys ekonomiczny przedmiotu i jego biografię; Tim Edensor, który uznał, że człowiek i rzecz zlewają się w rodzaj hybrydy, że doświadczamy przedmiotów w sposób cielesny, że to one nadają naszym zmysłom strukturę i kształtują pamięć naszego ciała. Pojawiające się $\mathrm{w}$ pracach twierdzenia o zagrożeniach związanych z przedmiotami, o kresie antropocentryzmu, wydają się przypominać wcześniejsze katastroficzne hasła o zalewie „żółtej rasy” i nuklearnej zagładzie. Warto podkreślić, że tego typu niepokoje sytuują się zazwyczaj w obrębie social sciences, nauk związanych ze społeczeństwem (jak historia, archeologia, socjologia, psychologia, ekonomia oraz antropologia i kulturoznawstwo), „wrażliwych” na odkrycia nauk technicznych. W sferze humanistyki arts (jak historia sztuki, filologia, muzykologia, niektóre działy filozofii) artefakty mają inny rys, który warto $\mathrm{w}$ tym momencie przypomnieć, związany z praktyką badawczą, bazującą na odwołaniach do tradycji i aksjologii. Owa „inność” nie oznacza jednak zapóźnienia wobec przemian w sferze technonauki i nie jest też rezultatem programowego konserwatyzmu. Humanista arts - egzystujący w skansenie kultury - to przede wszystkim erudyta przekonany o cykliczności przemian cywilizacyjnych, zachowujący dystans wobec technokratycznych przełomów. Warto zwrócić uwagę, że w czasie, gdy rozwijała się odmiana „socjalistycznej” etnografii, zupełnie inaczej postępowali, co można uznać za paradoks, semiotycy rosyjscy, którzy w podejściu do przedmiotów uwzględniali znacznie szerszy kontekst kulturowy, często bliski koncepcjom Eliadego, odnosząc się do przestrzeni mitologii i archetypów (zob. niżej Toporow). Warto również pamiętać, że koncepcja Latoura, kopiowana niekiedy w sposób bardzo techniczny w obręb nauk o sztuce, oparta jest na dość swobodnym potraktowaniu teorii względności Einsteina, na pomieszaniu pojęć „układu odniesien” w fizyce i „aktora” $\mathrm{w}$ semiotyce. Jak dowodzą analizy Alana Sokala i Jeana Bricmonta ${ }^{12}$, francuski socjolog błędnie rozumiał teorię względności, stąd stworzona

aktancyjne, pary postaci) omawia także A. Ubersfeld (Lire le théâtre, t. 1, Paryż 1996, polskie tłumaczenie Czytanie teatru I, przeł. J. Żurowska, Warszawa 2002).

12 A. Sokal, J. Bricmont, Modne bzdury. O nadużywaniu pojęć z zakresu nauk ścistych przez postmodernistycznych intelektualistów, przeł. P. Amsterdamski, Warszawa 2004, s. 124-131. 
przez niego teoria społeczna stanowi jedynie rodzaj swobodnej, autorskiej metafory, niemającej odniesienia w rzeczywistości i badaniach matematycznych.

W związku z wieloznacznością pojęcia „artefakt” w naukach społecznych uznaję, że w obrębie humanistyki arts zasadniej będzie mówić nie o „artefaktach”, ale „artefaktach kulturowych”, że takie dookreślenie zapewni rozważaniom bezpieczną precyzję. Zakładam, że przedmiot to rodzaj klucza, który wielokrotnie otwierał już drzwi „,́́wiata encyklopedii”, zanim podkreślę zalety takiego ujmowania kultury, dwie ważne konstatacje. Pierwsza to odpowiedź na pytanie, gdzie w sferze rozmaitych metodologii badawczych sytuuje się myślenie kategoriami artefaktu. Druga konstatacja stanowi rozwinięcie tej pierwszej i prowadzi do odpowiedzi na pytania: dlaczego „artefakt kulturowy” uznaję za pojęcie bardziej fundacyjne niż utrwalony w tradycji „motyw” i jaką przestrzeń mentalną otwiera nowe rozwiązanie terminologiczne?

\section{Artefakt w obszarze ujęć interdyscyplinarnych}

W gronie zwolenników wspólnoty sztuk trudno o jednomyślność w kwestii metodologii i przedmiotu badań. Badacze, którzy wypowiadają się twierdząco w kwestii pokrewieństwa słowa i obrazu, dokonują uogólnień na różnych poziomach, co sygnalizowała Seweryna Wysłouch w artykule Literatura a sztuki wizualne. Problemy metodologiczne ${ }^{13}$, wskazując powinowactwa na płaszczyźnie: prądów artystycznych, stylów i technik, tematów i motywów, w strukturze dzieł wielokodowych. Od czasu tej publikacji pole badawcze pogranicza znacznie się poszerzyło, ukazał się również tom zbierający polskie ujęcia teoretyczne, stworzone w XX wie$\mathrm{ku}^{14}$. Uwzględniając te dodatkowe obserwacje i modyfikując kategorie porządkujące, można zauważyć, że w sferze literacko-plastycznej czy plastyczno-literackiej ważne miejsce zajmują: badacze poszukujący tzw. niezmienników: w postaci struktur estetycznych (Stefan Morawski), języka żywiołów (Gaston Bachelard), tendencji artystycznych (Julian Krzyżanowski), archetypów (Carl Gustaw Jung). Istnieje duża grupa naukowców, których zajmuje badanie mechanizmów, którzy odnajdują wspólnotę sztuk na poziomie kompozycji (Ewa Wiegandt), narracji (Waldemar

13 S. Wysłouch, Literatura a sztuki wizualne. Problemy metodologiczne, [w:] Między tekstami. Intertekstualność jako problem poetyki historycznej, red. J. Ziomek, J. Sławiński, W. Bolecki, Warszawa 1992.

${ }^{14}$ Literatura a malarstwo - malarstwo a literatura. Panorama myśli polskiej XX wieku, red. G. Królikiewicz, O. Płaszczewska, I. Puchalska, M. Siwiec, Kraków 2009. 
Okoń), w procesie powstawania tropów (Seweryna Wysłouch). Niektórzy, uznając wyższość kategorii tradycji, badają poziom przeżycia estetycznego i wtedy interesują ich wzajemne inspiracje pomiędzy artystami i dziełami (zagadnienia ilustracji i ekfrazy) lub poruszają się na poziomie motywów i tematów (Jan Białostocki, Erwin Panofsky). Charakter interdyscyplinarny mają również badania sztuki i literatury poszerzone o kontekst neuropsychologii, skoncentrowane wokół zagadnień widzenia i wielozmysłowości, oraz analizy kulturowe Mike Bal, w których dzieła sztuki przywołują sferę społecznej interakcji. Gdy przyjrzeć się bliżej wybranym ujęciom badawczym, wtedy sprawa dodatkowo się komplikuje, okazuje się bowiem, że bardziej zasadne niż wybrany poziom wspólnoty sztuk jest zastosowane „spojrzenie”, fakt, czy ogląda się dzieła z perspektywy semiotycznej, hermeneutycznej czy empatycznej. Dowodem jest metodologiczne zróżnicowanie prac poświęconych ekfrazie, która uchodzić może za: rodzaj retorycznej figury myśli15, typ ćwiczenia wstępnego (gr. „progymnasmata", łac. praeexercitamenta) stosowanego w greckich i rzymskich szkołach „pięknej wymowy”, część tekstu (eposu, listu, elegii, sielanki czy pieśni) lub samodzielny gatunek o charakterze lirycznym lub epickim. W ujęciu semiotycznym, popularnym $\mathrm{w}$ świecie anglosaskim ${ }^{16}$, ekfraza zyskuje rys filozoficzny, prowadzi do rozważań o tym, czy język może przybliżać, uobecniać świat przedmiotów, jaka jest relacja pomiędzy znakami naturalnymi i sztucznymi; w ujęciu hermeneutycznym, socjologicznym, charakterystycznym dla naukowców niemieckich ${ }^{17}$, ekfrazę jako „wiersz o malarstwie” traktuje się jako rodzaj świadectwa odbioru sztuki, element recepcji sztuk plastycznych. Wstępnie mogę zatem powiedzieć, że „artefakt kulturowy” to obiekt, który przywołuje wprawdzie dawne analizy na poziomie tematów i motywów, który jednak można badać w różnorodny sposób, niekoniecznie kopiując zasady wypracowane przez Panofsky'ego i Białostockiego. Wybór strategii metodologicznej będzie zawsze zależał od zasobu wiedzy oraz temperamentu i światopoglądu. Wiele zależy od tego, czy szczęściem napełnia badacza ujęcie historyczne, gdy - jak opisał ten stan Heinrich Wölfflin - „sprawy przybierają kształt jasny i precyzyjny, zgodny ze swą genezą i ewolucją, a przedmioty tracą pozór zjawisk przypadkowych i stają się zrozumiałe, jako wyrastające

${ }^{15}$ Historię pojęcia omawiam w rozprawie Wiersze o obrazach. Studium z dziejów ekfrazy, Poznań 2009.

${ }^{16}$ M. Krieger, Ekphrasis. The Illusion of the Natural Sign, Baltimore 1992; J.A.W. Heffernan, Museum of Words. The Poetics of Ekphrasis from Homer to Ashbery, Chicago 1993.

17 G. Kranz, Das Bildgedicht. Theorie. Lexikon. Bibliographie, t. I-III, Köln-Wien 1981-1987. 
z konieczności"18. Czy też rezygnuje on z możliwości całkowitego poznania rzeczywistości, nigdy nie cofa się ku pierwotnej strukturze, a poczuciem szczęścia napełnia go analizowanie wybranych kodów. Prace poświęcone artefaktom kulturowym mają już w obrębie polskiej humanistyki arts swoją skromną, acz utrwaloną, tradycję ${ }^{19}$. „Lustro” doczekało się dwóch różnych ujęć Mieczysława Wallisa i Ireny Fijałkowskiej-Janiak; „katedra” w spojrzeniu literaturoznawczym (Małgorzaty Czermińskiej) została dopełniona o wątki ikonograficzne, „kula” w ramach analizy historyka sztuki (Beaty Purc-Stępniak) zyskała ważne odniesienia filozoficzne i filologiczne, w ostatnim czasie „lalka” stała się tematem ciekawej syntezy (Radosława Muniaka) uwzględniającej konteksty antropologiczne.

\section{"Motyw" a "artefakt kulturowy"}

Czas odpowiedzieć na pytanie, w czym „artefakt” może okazać się bardziej funkcjonalny od „motywu”? Odpowiedź ułatwi mi krótka rekonstrukcja znaczeń kojarzonych z „motywem” w literaturoznawstwie i nauce o sztuce.

\begin{tabular}{|c|c|}
\hline Nauka o sztuce & Literaturoznawstwo \\
\hline $\begin{array}{l}\text { „Świat czystych form, pojętych jako wy- } \\
\text { kładniki pierwotnych lub oczywistych zna- } \\
\text { czeń, nazwać możemy światem motywów } \\
\text { artystycznych". [E. Panofsky, Ikonologia } \\
\text { i ikonografia. Studia z historii sztuki, War- } \\
\text { szawa 1971, s. 13.] }\end{array}$ & $\begin{array}{l}\text { „Motyw - elementarna jednostka konstruk- } \\
\text { cyjna świata przedstawionego w utworze, } \\
\text { składnik pierwiastkowy (przedmiot, sytua- } \\
\text { cja, zdarzenie); łączy się w wątki lub tematy } \\
\text { (zespoły wyższego rzędu)”. [Słownik termi- } \\
\text { nów literackich, red. J. Sławiński, Wrocław } \\
\text { 1989.] }\end{array}$ \\
\hline
\end{tabular}

W obu dziedzinach „motyw” - traktowany jako układ konstrukcyjny (bądź układ formalny20) - jest w sposób ścisły powiązany z tematem,

18 H. Wölfflin, Das Erklären von Kunstwerken, Leipzig 1940, s. 16; cyt. za: H. Hatzfeld, Literatura w świecie sztuki, przeł. M. Kaniowa, [w:] H. Markiewicz, Wspótczesna teoria badań literackich za granica. Antologia, t. 2, Kraków 1972, s. 258.

19 M. Wallis, Dzieje zwierciadta i jego rola w różnych dziedzinach kultury, Warszawa 1973; B. Purc-Stępniak, Kula jako symbol „vanitas”. Z kręgu badań nad malarstwem XVII wieku, Gdańsk 2004; M. Czermińska, Gotyk i pisarze. Topika opisu katedry, Gdańsk 2005; I. Fijałkowska-Janiak, Lustro. Literatura - kultura - język, Gdańsk 2010; R.F. Muniak, Efekt lalki: lalka jako obraz i rzecz, Kraków 2012.

20 Motywy to przede wszystkim „układy formalne”, natomiast „tematy są zawsze obciążone znaczeniem, skoro wymagają ustaleń semantycznych”. Podaję za: L. Kalinowski, 
kompozycją i wątkiem. Panofsky uznawał, że motyw, wyodrębniony $\mathrm{w}$ fazie opisu preikonograficznego, łączy się płynnie $\mathrm{z}$ tematami lub pojęciami w toku analizy ikonograficznej, przywołując tym samym źródła literackie. Jednak praktyka badawcza nie potwierdziła tej płynności. Zasadę podważył Roman Ingarden, który zauważył, że „temat literacki i przedmioty (rzeczy i ludzie) przedstawione w obrazie stanowią dwa różne składniki obrazu”, czego „dowodzi najlepiej fakt, że istnieją obrazy, które wolne są od tematu literackiego i które mimo to przedstawiają pewne przedmioty"21. To nie jedyna wątpliwość związana z zastosowaniem kategorii „motywu”. Okazywało się, że analizy motywów i wątków przekraczają ramy konstrukcyjne utworu, przywołując sferę archetypów, jak np. w pracy Mieczysława Porębskiego, który, badając wątki neosarmackiego mitu królewsko-hetmańsko-rycerskiego w malarstwie Piotra Michałowskiego, zauważył: „Są w nim wątki, nad którymi pochylają się tysiąclecia, wątki rozmierzające całe epoki kultur i cywilizacji”22. Inną usterkę w strategii badacza motywów odkrył sam Jan Białostocki, gdy analizując motyw vanitas $\mathrm{w}$ poezji i sztuce na przestrzeni od średniowiecza do XIX wieku, skonstatował, że jego badania są niepełne, gdyż nie uwzględnił kultury azjatyckiej, a to dopiero pozwoliłoby na pełne ujęcie problemu. Powyższe zastrzeżenia sprawiły, że omawiana metodologia nie zyskała w naukach o sztuce ponadczasowej popularności. W okresie dominacji strategii semiotycznej badania motywów, jako niezgodne z teorią znaku, nabrały rysów staroświeckich. Można też zauważyć, że motyw, choć w ujęciu teoretycznym nienaganny, często odsłaniał swe prawdziwe oblicze dopiero w toku praktyki, prowadził do prac mało problemowych, ujęć o niejasnym i szerokim zakresie ${ }^{23}$, opartych na przekonaniu, że poza „przedmiotem” równorzędnym analizom mogą podlegać również „sytuacja i zdarzenie”. Sadzę, że wybór artefaktu jako kategorii porządkującej pozwala na doprecyzowanie strategii badawczej, mimo rzeczowej konkretyzacji nie zawęża obrazu badań, uruchamia bowiem szerokie pole odniesień z zakresu estetyki i ontologii.

Motywy antyczne $w$ dekoracji Kaplicy Zygmuntowskiej, „Folia Historiae Artium” 1976, t. 12 , s. 69 i 91.

${ }^{21}$ R. Ingarden, O budowie obrazu. Szkice z teorii sztuki, Kraków 1946, s. 3-14.

${ }_{22}$ M. Porębski, $Z$ problematyki metodologicznych badań nad ikonografia polskiego romantyzmu, [w:] Romantyzm. Studia nad sztuka drugiej połowy wieku XVIII i wieku XIX, Warszawa 1967, s. 98.

${ }^{23}$ Zob. słowniki zredagowane zgodnie z definicją motywu, szerzej pisałam na ten temat w artykule Artefakty w humanistyce (rekonesans), [w:] Kultura - Język - Edukacja. Dialogi współczesności z tradycja, red. B. Gromadzka, D. Mrozek, J. Kaniewski, Poznań 2008 . 


\section{Artefakt w przestrzeni wizualnej i słownej}

Artefakt kulturowy to rodzaj badawczego obiektu, którym może być tekst (napisany, wypowiedziany), partytura i wykonanie dzieła muzycznego, dzieło plastyczne (obraz malarski, dzieło rzeźbiarskie, architektoniczne, inne), film. W malarstwie termin „obraz” ma różne odniesienia. To picture - obraz będący rzeczą fizyczną, ujętą w ramy, którą Roman Ingarden nazywał „malowidłem”24, myśląc o przedmiocie wiszącym na ścianie, który z upływem czasu może zmieniać swe wymiary. To także image - obraz będący efektem postrzegania, obraz mentalny, który powstaje w umyśle, bywa odtwarzany w pamięci, wyobraźni, nie ma bezpośredniego związku z rzeczywistością. Można zauważyć, że obrazy kreowane $\mathrm{w}$ świadomości zawierają jednak pewne elementy struktury estetycznej, a „obrazy niemożliwe”, jak fotografia i film, mają naturę dwoistą, są jednocześnie fikcyjne i rzeczywiste. Można też wskazać, że obrazy funkcjonujące w erze technologii medialnych zachowują się podobnie jak obrazy w magii, gdzie słowo „reprezentacja” zdaje się zacierać; że informacja $\mathrm{w}$ przekazie wirtualnym pozostaje $\mathrm{w}$ organicznym związku $\mathrm{z}$ medium, które odgrywa istotną rolę w kształtowaniu sensu. Podobne dylematy związane są również z przestrzenią literacką, gdzie funkcjonują tak różnorodne zjawiska kulturowe, jak: wizualność i dotykalność słowa, „fizjonomia litery", carmina figurata i formy poezji wizualnej, liberatura i architektonika tekstu literackiego. „Rematyczność”25 pisma i książki to zwyczaj traktowania słowa sięgający czasów kultury oralnej, gdy żywa była wiara $\mathrm{w}$ jego rzeczową substancję, czego śladem jest hebrajskie dabar (tłumaczone na język grecki jako rhema i logos)26. W Księdze Rodzaju zrównuje ono takie znaczenia, jak: „mowa, słowo” i „czyn”, które, zgodnie z tradycją judaistyczną, uświęcało miejsce, w jakim się „rozlegało”27. Mówienie o „przedmiotowości” ma w kulturze polskiej dwóch wyjątkowych patronów, a ich wpływ na rozwój omawianego tematu jest nie do przecenienia. Autorem pierwszego ujęcia jest Tadeusz Kantor. Z jego szkicu spisanego pod koniec życia - Moja twórczość, moja podró́̇ - wyni$\mathrm{ka}$, że przedmiot zawsze traktował z najwyższą powagą, lokując go „pomiędzy śmietnikiem a wiecznością". Wspominał, że tuż po wojnie przed-

${ }^{24}$ R. Ingarden, O budowie obrazu, [w:] tenże, Studia z estetyki, t. 2, Warszawa 1958.

${ }^{25}$ Por. pojęcia „rematu” i „tematu” w wykładni J. Ziomka, Metafora a metonimia. Refutacje i propozycje, [w:] Prace ostatnie. Literatura i nauka o literaturze, Warszawa 1994, s. $178-220$.

${ }^{26}$ Tak pojmowany akt mowy stanowi podstawę teorii interpretacji stworzonej przez H. Blooma, Mapa przekrzywień, przeł. A. Lipszyc, „Literatura na Świecie” 2003, nr 9-10.

27 J. Tokarska-Bakir, Sensorium sensualizmu, [w:] taż, Obraz osobliwy. Hermeneutyczna lektura źódet etnograficznych. Wielkie opowieści, Warszawa 2002, s. 244. 
mioty wyjęte z życiowej rzeczywistości, obłocone koło od wiejskiego wozu czy zmurszała deska z płotu, nosiły znamię biedy, służyły zatrzymaniu i utrwalaniu doświadczeń. Później, w latach sześćdziesiątych XX wieku, sytuował przedmioty na przeciwnym biegunie świadomości, twierdząc, że pozwalają mu oderwać się od głębi własnego ,ja”. Artysta, tworząc Ambalaże, wiedział, że nadszedł kres deformacji, przekształcania, interpretacji, że przestało się liczyć odbicie rzeczywistości w sztuce, ale był pewien, że nie przestał się liczyć sam przedmiot. „Miałem z nimi dużo zabawy, ich wieloznaczność i aluzyjność pomagały mi świetnie w mówieniu o wielu sprawach, z którymi nie mogłem się uporać. Po prostu one mówiły za mnie"28. Zbigniew Herbert, podobnie jak Kantor, doceniał egzystencjalny i wychowawczy sens przedmiotu, opisując go przede wszystkim z perspektywy widza i podkreślając w ten sposób swoją małość wobec świata rzeczy. Uznawał, że takiego szacunku nauczyli go mistrzowie holenderscy ${ }^{29}$ i ich obrazy, wyzwolone od religijnego kultu, będące świadectwem czystego, malarskiego widzenia. Gdy zmieniał perspektywę (Studium przedmiotu, 1961) i opisywał malarstwo z pozycji kreatora, malarza, który jak Malewicz „wzlatuje ku bezprzedmiotowym wyżynom sztuki”30, wtedy zakładał maskę, pozostając jednocześnie po stronie „wiary w konkret”. „Nie jako materialista, ale jako ten, który wie, że tylko pełna akceptacja zmysłowego świata może doprowadzić do poznania Istoty"31. Praktyka artystyczna Herberta (np. opowieści o katedrach) budziła wiele kontrowersji, zarzucano mu plagiat i „odtwórczość". Jego opowieści o przedmiotach przypominają jednak wcześniejsze, modernistyczne relacje o symbiozie człowieka z rzeczami, które oparte były na wierze, że świat ma jednorodną, materialno-duchową strukturę, że przedmiot może stać się znakiem wewnętrznego życia człowieka i że jest $\mathrm{z}$ nim związany $\mathrm{w}$ sensie duchowym. Analizy kulturowe poety, mimo zastrzeżeń historyków sztuki, zawsze przebiegały według określonego schematu. Jako interpretator nie lokował dzieła sztuki poza światem społecznym i kulturową formacją, nie zgadzał się, by obraz mówił sam za siebie, jednak w złożonej relacji między badaczem, ramami interpretacji a przedmiotem, dbał o to, by to przedmiot miał zawsze prawo do ostatniego zdania.

${ }_{28}^{2}$ T. Kantor, Moja twórczość, moja podróż, cyt. za: <www.cricoteka.com.pl> [25.07. 2007].

29 Podobne nastawienie znaleźć można w szkicach Z. Bieńkowskiego Wewnętrzne zwiazki sztuki, inspirowanych przez studium R. Barthes'a Świat-przedmiot z 1964 roku.

30 Cyt. za: A.M. Rymkiewicz, Zbigniew Herbert „Studium przedmiotu”, [w:] Liryka polska. Interpretacje, red. J. Prokop, J. Sławiński, Kraków 1971.

${ }^{31} \mathrm{M}$. Tabor, Za przyktadem Waszej Wysokości... - nowe konteksty „Studium przedmiotu" Zbigniewa Herberta, [w:] Wyraz wytuskany z piersi. Szkice o twórczości Zbigniewa Herberta, red. J.M. Ruszar, Lublin 2006. 


\section{Artefakty jako "przedmioty troski”}

Obserwacja, że rzeczowość przywołuje sferę ducha, to myśl, która jest wyraźnie obecna zarówno w pismach hermeneutów, jak i semiotyków. „Artefakt” to pojęcie datowane, mające swoją historię, które uruchamia grecką i łacińską etymologię: gr. pragmata to rzeczy rozumiane jako „przedmioty troski”; łac. arte factum to „rzeczy sztucznie wytworzone”. Gdy Martin Heidegger pisał o sporze ziemi i nieba wyróżniającym prawdziwą sztukę, twierdził, że droga do genialnego dzieła zaczyna się właśnie w świecie rzeczy, gdy rzecz w wyniku artystycznej stylizacji nabiera cech narzędzia. Za przykład tego, co „narzędziowate” w sztuce, posłużyła mu para chłopskich butów, odkryta (odsłonięta) na obrazie van Gogha ${ }^{32}$, w opisie płótna wyliczył wszystkie istotne cechy tego przedmiotu, jak: materiał, służebność, poręczność, niezawodność, stopień zużycia ${ }^{33}$. W odczycie na temat „rzeczy” ubolewał, że w dobie rozwoju aparatury telewizyjnej i nowych form komunikacji zmniejszone w sposób fizyczny odległości nie zapewniają nam jednocześnie stanu bliskości z rzeczami. Jego obserwacje na temat istoty rzeczy ${ }^{34}$ odsłaniają ścisły związek, jaki łączy sposób pojmowania rzeczowości z jej językowymi określeniami. „Rzeczy” odpowiadają terminy res („to, co nas obchodzi”) albo rzymskie causa („sprawa”, „przypadek”). W związku z czym, gdy mówimy o rzeczy, wrażenie materialności („coś, co jest”) zastępowane jest wrażeniem bliskości. Chodzi o uległość wobec siebie, „gdy myślimy rzecz jako rzecz, pozwalamy, by obeszła nas światująca istota rzeczy, jesteśmy «u-rzeczeni» (Be-Dingten)"35. Te ustalenia okazują się bliskie intuicjom Toporowa, który, zainspirowany wykładem, pisał o „formującej więzi człowieka z rzeczą"36. Zajmowanie się przedmiotami pozwala obserwatorowi pokonać dystans pomiędzy sobą a światem. Jak ujmował to Heidegger, rzecz to sposób przejawiania się czterech ważnych elementów: „z siebie ze sobą zgodne, ziemia i niebo, istoty boskie i śmiertelni należą do siebie nawzajem z jedni zgodnej czwórni" 37 . Jako śmiertelni odgrywamy zatem ważną rolę $\mathrm{w}$ funkcjonowaniu artefaktu. Przedmiot wyzwala podmiot. Rozwija-

32 Zob. V. van Gogh, Buty, 1887, olej na płótnie, 34 x 41,5 cm, Baltimore Museum of Art.

${ }^{33}$ Zob. M. Heidegger, Holzwege, [w:] tenże, Dzieła zebrane, t. 5, Frankfurt nad Menem 1978; opis obrazu za: C. Woźniak, Martina Heideggera myślenie sztuki, Kraków 2004.

${ }^{34}$ Odczyt wygłoszony 6 marca 1950 roku w Bawarskiej Akademii Sztuk Pięknych, opublikowany w roczniku Akademii: Gestalt und Gedanke, red. Clemens hr Podewils, t. 1, München 1951.

35 M. Heidegger, Rzecz, [w:] tenże, Odczyty i rozprawy, przeł. J. Mizera, Kraków 2002, s. 161.

36 W.N. Toporow, Rzecz w perspektywie antropocentrycznej. Apologia Pluszkina, [w:] tenże, Przestrzeń i rzecz, przeł. B. Żyłko, Kraków 2003.

${ }^{37}$ M. Heidegger, Rzecz, s. 158. 
jąc tę myśl, semiotyk rosyjski33 zauważył, że ważne jest rozgraniczenie, które powinniśmy wprowadzić do sfery kultury, oddzielając „przedmioty słabe” i „rytualne” - czyli te tworzące górny biegun aksjologiczny (co eliminuje z pola rozważań wiele przedmiotów użytkowych). Odtwarzając relacje człowiek - rzecz, uznał, że rzecz zawsze będzie wtórna i podrzędna, zaś człowiek zawsze będzie jej demiurgiem, co jednak nie przeszkadza, by mówić o wzajemnej bliskości i intymnej duchowej więzi między tymi dwoma elementami. Wskazał, że świat rzeczy, odwrotnie niż natura, „odciąga od tego, co kosmiczne”, „kompensując człowiekowi kosmiczną bezdomność przez ciepło domowego ogniska". Z racji tego, że rzecz zwrócona jest ku człowiekowi swoimi właściwościami: „materiałem, fakturą, formą, barwą, swoją geometrią, składem, podzielnością, kompozycją, swoją temperaturą, zapachem, dźwiękiem”, zawiera w sobie projekt „związków głębokich, intymnych i bezinteresownych”, gdyż „właściwości odsłaniają głębinową strukturę rzeczy i odnoszą ją do «fizykalnochemicznego» składu świata i jego geometrii". Toporow zwrócił jeszcze uwagę na dwa istotne elementy „formującej więzi człowieka z rzeczą”. Pierwszy to konstatacja, że w cechach rzeczy-przedmiotu człowiek w pewnym stopniu, jak w zamglonym zwierciadle, rozpoznaje sam siebie jako podmiot percepcji właściwości rzeczy. Druga uwaga to refleksja, że „człowiek dobrowolnie i nieskrępowanie dzieli się z rzeczą, jak gdyby pomniejszając siebie i zniżając się do niej”, przenosi na nią część aury roztaczanej przez ducha i duszę. Toporow w trakcie analiz prozy rosyjskiej zwracał także uwagę na pracę włożoną w rzecz, która także staje się przedmiotem sentymentalnych ujęć i estetycznych przeżyć, co poszerza dodatkowo spectrum duchowej więzi człowieka z „rzeczowością”.

\section{Narratyzwizm a historia przedmiotu}

Jak ujmować kulturowy artefakt? Zgodnie z logiką temporalną czy aktancyjną? Wydaje się, że choć poszukiwanie logiki w czasowości wciąż cieszy się popularnością (chociażby w nauczaniu historii literatury), jednak rozumienie historii modyfikuje obecnie praktyka sztuki. Wedle diagnozy Nicolasa Bourriauda ${ }^{39}$, procesy kulturowe mają charakter swobodny, a kultura zachowuje się podobnie jak korzeń (radicant), rozwija się tam, gdzie znajdzie dogodne warunki, w zależności od potrzeb związanych ze wzrostem. Ta organiczna metafora przywołuje wcześniejsze pomysły Umberta Eco, który traktował kulturę jak labirynt o naturze kłą-

38 W.N. Toporow, Rzecz $w$ perspektywie antropocentrycznej..., poniższe cytaty pochodzą ze s. 132-134.

${ }^{39}$ N. Bourriaud, Estetyka relacyjna, przeł. Ł. Białkowski, Kraków 2012, s. 31. 
cza, „las o rozwidlających się ścieżkach"40, w czym bliski był rhizome G. Deleuze'a i F. Guattariego ${ }^{41}$. Z koncepcjami „sieci” wiązała się określona strategia badawcza, chodziło o puszczenie w ruch świata encyklopedii, zgodnie z zasadą: „żadna całostka kulturowa nie da się wytłumaczyć przez odesłanie do jakiejś platońskiej, psychicznej lub przedmiotowej jednostki" 42 , że w świecie znaków trudno odkryć jakiś wewnętrzny schemat. Eco w późnych zapiskach ${ }^{43}$ krytycznie ocenił praktyczne działania niektórych interpretatorów, stosujących nieograniczoną semiozę, którzy uprawiali interpretację pozbawioną kryteriów, akcentując nadmiernie własne prawa. Od czasu stworzenia tej teorii sztuka objaśniania sztuki wzbogaciła się o nowe odniesienia, m.in. kategorię doświadczenia, nieprzewidywalnej osobowości, bierze także pod uwagę elementy płci, rasy i środowiska, otwiera się na naturę, na odkryte w nowy sposób psychologizm i psychoanalizę. Tak odsłonięta przestrzeń badawcza ${ }^{44}$ skłania do poszukiwania nowych metodologii. Współcześnie nadmiar informacji sprawia, że często rezygnujemy z narracji na rzecz opisu, który zapewnia nam bezstronny udział w „grze pozbawionej początku i końca”45. Wobec artefaktów kulturowych nie chcę jednak porzucać narracyjnej formy dochodzenia do wiedzy. Opowieść przykuwa zainteresowanie, uruchamia tryb interpretacyjny, to rodzaj procedury, która zyskuje nową jakość w psychoanalizie, w stworzonej tam narracyjnej konstrukcji ludzkiej psychiki. Poza tym, sama narracja, jak wskazują językoznawcy, jest także formą myślenia, to - według Tomasza Woźniaka - „proces interpretowania świata za pomocą języka"46. Formuła spajająca w badaniach może

40 Eco koncepcję omawia w Dopiskach do Imienia róży, gdzie wyróżnia labirynt klasyczny, manierystyczny i sieć - labirynt kłącze, w którym „każda droga może się skrzyżować z dowolną inną. Nie ma środka, nie ma peryferii, nie ma wyjścia, ponieważ kłącze jest potencjalnie nieskończone. Przestrzeń domysłów jest przestrzenią o naturze kłącza". U. Eco, Imię róży, przeł. A. Szymanowski, Warszawa 1988, s. 612.

${ }^{41}$ Pomysł opisany w: G. Deleuze, F. Guattari, Capitalisme et Schizophrenie, t. 2, Paris 1980; fragment w polskim przekładzie Kłacze, przeł. B. Banasiak, „Colloquia Communia” 1988, nr 1-3.

42 U. Eco, Lector in fabula, [w:] P. Bondanella, Umberto Eco. Semiotyka, literatura, kultura masowa, przeł. M.P. Markowski, Kraków 1997, s. 83.

${ }^{43}$ U. Eco, Autor, tekst, interpretatorzy, [w:] Wyznania młodego pisarza, przeł. J. Korpanty, Warszawa 2011.

${ }^{44}$ Ciekawą propozycję badawczą, związaną z kategorią „sieci”, proponuje R. Nycz w artykule Lekcja Adorna: tekst jako sposób poznania albo o kulturze jako palimpseście, „Teksty Drugie” 2012, nr 3.

${ }^{45}$ L. Manovich, Język nowych mediów, przeł. P. Cypryański, Warszawa 2006, s. 332.

46 T. Woźniak, Perspektywy badania narracji - między humanistyka a neuronauka, [w:] Przeobrażenia w języku i komunikacji medialnej na przełomie XX $i$ XXI wieku, red. M. Karwatowska, A. Siwiec, Lublin 2010, s. 209. 
mieć różny charakter, przypuszczam, że każdy artefakt kulturowy będzie potrzebował innego uporządkowania, które zależeć będzie od jego cech specyficznych, dostępnych $\mathrm{w}$ formie informacji wejściowych. Nie chodzi mi jednak o szybkie poruszanie się w sieci, gromadzenie i przekazywanie danych, techniczne kopiowanie procesów zachodzących w ludzkim układzie nerwowym (sieci neuronowe) do sfery badawczej. Przyznaję, że ideałem dobrze zorganizowanych relacji jest urządzenie działające $\mathrm{w}$ sposób cybernetyczny, na zasadzie sprzężenia zwrotnego, jak np. termostat, który odpowiada na chłód pokoju przez włączenie ogrzewania i tym samym zmienia jego temperaturę. Jednak badacz $\mathrm{w}$ relacjach pomiędzy umysłem, rzeczywistością a przedmiotem nigdy nie osiągnie stanu takiej technologicznej precyzji. Może jedynie poszukiwać złotego środka pomiędzy sferą swojego umysłu a przedmiotem. Ważna konstatacja jest również taka, że sieć aktywnych odniesień i przekształceń, budujących wędrówkę po „lesie o rozwidlających się ścieżkach”, wymaga wyraźnych punktów orientacyjnych, namacalnego pnia drzewa (schemat narracyjny), do którego zawsze powrócić możemy, gdy utkwimy w gęstwinie kłącza.

\section{Koncepcja - perspektywy i zagrożenia}

Artefakt kulturowy jest stabilny, fizyczny i wytłumaczalny, stanowi punkt oparcia i dobry punkt wyjścia do przestrzeni poznania. Jego charakterystyka przywołuje problem związany z kategorią „rzeczowości”, którego unikałam w dotychczasowych rozważaniach, a którego uniknąć się nie da. Gdy Ingarden rozważał, czym jest „realna całość” w odniesieniu do dzieła architektonicznego, radził, by nie nazywać jej „budowlą,, „kościołem” czy „świątynią”, gdyż w ten sposób uruchamiamy jedynie „akty intencjonalne” związane ze „stosem kamieni”47. Uznawał, że „dzieło sztuki - jakiegokolwiek by było rodzaju - nie jest przedmiotem realnym sensu stricto, i nie jest w ogóle żadnym przedmiotem bytowo samoistnym, lecz odznacza się pewną zasadniczą, niedającą się w żadnej odmianie sztuki wyrugować bytową względnością, podziałem na akty i postawy subiektywne: wytwórcze akty artysty”48. Z kolei „realna całość” - jako samoistna wobec aktów świadomości - nie ulega zmianom w procesie „dokonania się”. Wyraźnie zatem podkreślał rozbieżność pomiędzy „rzeczowością” materiału („przedmiotu podstawowego”) a dziełem sztuki, które stanowi ucieleśnienie („urzeczowienie”) idei i tęsknot artystycznych

${ }^{47}$ R. Ingarden, $O$ dziele architektury, [w:] tenże, Studia z estetyki, t. 2, Warszawa 1958, s. 115-125.

48 Tamże, s. 150-153. 
twórcy. To ważna konstatacja, sugerująca rozpiętość interpretacji. Artefakt jest przedmiotem, a jednocześnie pozostaje relacją o przedmiocie i wyrazem intencji związanych z odbiorem przedmiotu. Artefakt wskazuje kierunek myślenia, który biegnie od świata materii do świata wiedzy o sztuce i literaturze, od świata rzeczy do wiedzy humanistycznej. Może jednocześnie ucieleśniać preferencje, wartości i normy społeczne, a według Lorenza Magnaniego, pełnić nawet funkcje instrumentu etycznego, „reprezentacji, które przekształca dane zdanie”49. W myśl jego koncepcji, różnej od ujęcia Latoura, reakcja moralna w sieci nadal przysługuje człowiekowi i polega na uruchomieniu milcząco przyjmowanych szablonów reagowania. Zdaniem Magnaniego, manipulujemy elementami otoczenia, „myślimy za pomocą oczu i rąk”, ale inferencje moralne dokonują się poza naszym umysłem. Zbiorowość, aby istnieć, potrzebuje czegoś w rodzaju kleju, jakieś „formuły spajającej”, a w tej kwestii raczej nie pomagają wypracowane wcześniej definicje kultury, w ramach których dzieli się ją na sfery: materialną (narzędzia, struktury architektoniczne), symboliczną (dzieła artystyczne traktowane jako „pamięć zewnętrzna ludzkiego umysłu") i socjetalną (role zawodowe i interakcje społeczne)50. Przyjęcie koncepcji artefaktów może zaowocować zespoleniem tej przestrzeni. Może również poszerzyć badania interdyscyplinarne o spójną metodologię, wspólną dla literaturoznawstwa, filmoznawstwa, nauki o sztuce, która szukać będzie inspiracji w socjosemiotyce, analizie kulturowej, antropologii literatury i sztuki, koncepcjach wizualizacji.

Przyjęcie takiej koncepcji wiąże się także z wątpliwościami. Czy zestaw kulturowo ważnych przedmiotów powinien wyglądać np. w następujący sposób:

1. Bańka mydlana - koło, kula

2. Laska - kij, kaduceusz

3. Lustro

4. Okno - rama

5. Krzyż

6. Perła

7. Medalion - nagrobek, klepsydra

8. Katedra, dom, labirynt

9. Miecz - oszczep, dzida, kopia

10. Lalka - marionetka, kukiełka

${ }^{49}$ L. Magnani, Morality in a Technological World. Knowledge as Duty, CambridgeNew York-Melbourne 2007, na podstawie relacji Ewy Bieńczyk, „Zwrot ku rzeczom” we wspótczesnej humanistyce, [w:] taż, Technonauka w społeczeństwie ryzyka. Filozofia wobec niepożądanych następstw praktycznego sensu nauki, Torun 2012.

50 J. Kozielecki, Transgresje i kultura, Warszawa 1997, s. 181-182. 
11. Puchar - kielich, dzban, puszka

12. Krzesło - tron

13. Most, drzwi

14. Maska

15. Dzieło - księga, obraz, rzeźba...

16. Totemy: wilk, kruk, motyl, szczur, sosna, pszczoła, hybryda...?

Czy zastosowanie koncepcji nie przerodzi się w rejestrację dzieł? Czy wyodrębniony system artefaktów buduje rodzaj europejskiego kanonu estetycznego? Czy wyłoniony zestaw przedmiotów znaczących ma charakter globalny czy lokalny (europejski)? Czy przedmioty są w jakiś sposób zróżnicowane (np. ze względu na płeć)? Czy zastosowanie koncepcji nie doprowadzi nas do odkrycia stereotypów artefaktowych (np. krzyż zyskujący negatywne konotacje $\mathrm{z}$ punktu widzenia kultur nieeuropejskich, poddawanych przymusowej chrystianizacji)? Czy tropiąc artefakty kulturowe, poszerzymy w jakimś stopniu naszą wiedzę o ludzkiej tożsamości?

Nie wszystko pozostaje w sztuce czytelne, pewien sens utrwala się, inny zanika, kolejne odczytania wzbogacają dzieło, ale nigdy nie zamykają kręgu związków kulturowych i zapożyczeń. Wobec bogactwa kultury trzeba zachować rozsądek. Dawne porządkowanie dzieł w ciągach intertekstualnych straciło swoją świeżość, gdyż związana z nimi postawa badawcza zakładała poczucie wyższości podmiotu i niemylność jego sądów. Nasze ambicje, jeżeli chodzi o historyczność przedmiotu, wzrosły, zgodnie z horyzontem zakreślonym przez Toporowa i Heideggera. Chodzi zatem o ujęcie procesu u samych źródeł. O zaobserwowanie momentu, gdy sytuowano na wzgórzach pierwsze świątynie, okalając w ten sposób przestrzeń zajmowaną przez boga (Heidegger), gdy człowiek i poprzedzający go homonidzi, począwszy od górnego paleolitu, zaczęli wytwarzać rzeczy albo wykorzystywać wytwory przyrody w rzeczowej funkcji (Toporow). Chodzi zatem o pochylenie się nad kulturowym artefaktem, niczym nad „kością pamięci”, z archeologicznym zapałem i przekonaniem, że odnaleźliśmy ważne wykopalisko, z nadzieją, że otwarcie zasobu pamięci, rekonstrukcja sieci powiązanych ze sobą w misterny sposób dzieł sztuki ${ }^{51}$ pozwoli nam dowiedzieć się czegoś więcej o sobie. Chodzi też o rodzaj autorskiej, metodologicznej swobody, gdyż: „Mnemozyne, muza pamięci, tzn. muza przyswojenia przez przypomnienie, która tu panuje, jest zarazem muzą duchowej wolności”52.

51 Próbą zastosowania koncepcji jest książka Bańka mydlana. Artefakt $w$ przestrzeni pamięci, Poznań 2013.

52 H.-G. Gadamer, Aktualność piękna. Sztuka jako gra, symbol i święto, przeł. K. Krzemieniowa, Warszawa 1993, s. 12. 


\section{BIBLIOGRAFIA}

Heidegger M., Rzecz, [w:] Odczyty i rozprawy, przeł. J. Mizera, Kraków 2002.

„Kultura Współczesna” 2008, nr 3 (Antropologia rzeczy).

Olsen B., W obronie rzeczy. Archeologia i ontologia przedmiotów, przeł. B. Shallcross, Warszawa 2013.

Rzecz i rzeczowość w kulturze XX $i$ XXI wieku, red. M. Kitowska-Łysiak, M. Lachowski, Lublin 2007.

Rzeczy i ludzie. Humanistyka wobec materialności, red. J. Kowalewski, W. Piasek, M. Śliwa, Olsztyn 2008.

Sulima R., Antropologia codzienności, Kraków 2000.

Toporow W., Przestrzeń i rzecz, przeł. B. Żyłko, Kraków 2003. 